\title{
Pengaruh Penggunaan Media Berbasis Internet, Motivasi Intrinsik dan Motivasi Ekstrinsik Terhadap Minat Berwirausaha Online Mahasiswa Universitas Tridinanti Palembang
}

\author{
Dian Septianti ${ }^{1)}$, Melia Frastuti ${ }^{2)}$ \\ 1) Program Studi Manajemen Universitas Tridinanti Palembang \\ 2) Program Studi Akuntansi Universitas Tridinanti Palembang \\ Jalan Kapten Marzuki No. 2446 Kamboja Palembang Kode Pos 30129 \\ Email: dianseptianti@univ-tridinanti.ac.id ${ }^{1)}$, melia frastuti@univ-tridinanti.ac.id ${ }^{2)}$
}

\begin{abstract}
This study aims to analyze the influence of the use of internet-based media, intrinsic motivation and extrinsic motivation on the online entrepreneurial interest of Tridinanti University Palembang students. Data analysis methods used are qualitative and quantitative, with primary and secondary data sources in the form of questionnaires, interviews and documentation. The population in this study were all students of the University of Tridinanti Palembang with the sampling technique is sampling proportionate stratified random sampling, while the samples obtained amounted to 100 respondents. The results showed that there was a significant influence between the use of internet-based media, intrinsic motivation and extrinsic motivation on the online entrepreneurial interest of Palembang Tridinanti University students simultaneously with Sig 0,000. While partially also found the influence of the use of internet-based media, intrinsic motivation and extrinsic motivation, where the use of internet-based media is the most influential variable on online entrepreneurial interest.
\end{abstract}

Keywords: Use of Internet-Based Media, Intrinsic Motivation, Extrinsic Motivation, Online Entrepreneurial Interest

\begin{abstract}
ABSTRAK
Penelitian ini bertujuan untuk menganalisis pengaruh penggunaan media berbasis internet, motivasi intrinsik da motivasi ekstrinsik terhadap minat berwirausaha online mahasiswa Universitas Tridinanti Palembang. Metode analisis data yang digunakan adalah kualitatif dan kuantitatif, dengan sumber data primer dan sekunder berupa angket, wawancara dan dokumentasi. Populasi dalam penelitian ini adalah seluruh mahasiswa Universitas Tridinanti Palembang dengan teknik sampling adalah sampling proportionate stratified random sampling, adapun sampel yang diperoleh berjumlah 100 responden. Hasil penelitian menunjukkan bahwa ada pengaruh yang signifikan antara penggunaan media berbasis internet, motivasi intrinsik da motivasi ekstrinsik terhadap minat berwirausaha online mahasiswa Universitas Tridinanti Palembang secara simultan dengan Sig 0,000. Sedangkan secara parsial juga ditemukan pengaruh penggunaan media berbasis internet, motivasi intrinsik dan motivasi ekstrinsik, dimana penggunaan media berbasis internet menjadi variabel yang paling berpengaruh terhadap terhadap minat berwirausaha online.
\end{abstract}

Kata kunci: Penggunaan Media Berbasis Internet, Motivasi Intrinsik, Motivasi Ekstrinsik, Minat Berwirausaha Online 


\section{Pendahuluan}

Perekonomian memiliki peranan penting dalam pembangunan suatu Negara. Apabila perekonomian bangsa kuat maka tentu saja akan semakin mudah dalam memajukan bangsa sehingga diharapkan mampu meningkatkan kesejahteraan yang adil dan merata.

Kehadiran dan peranan wirausaha akan memberikan pengaruh terhadap kemajuan perekonomian dan perbaikan pada keadaan ekonomi di Indonesia sekarang ini karena wirausaha dapat menciptakan lapangan kerja, meningkatkan kualitas hidup masyarakat, meningkatkan pemerataan pendapatan, memanfaatkan dan memobilisasi sumberdaya untuk meningkatkan produktivitas nasional, serta meningkatkan kesejahteraan pemerintahan. Berdasarkan pendapat tersebut, kewirausahaan dapat mempengaruhi tingkat pertumbuhan ekonomi Indonesia (yoannasiagian.files. wordpress.com). Dengan demikian, meningkatnya perkembangan kewirausahaan dapat meningkatkan perekonomian di Indonesia.

Sumbangan kewirausahaan terhadap pembangunan ekonomi suatu negara tidaklah disangsikan lagi. Suatu negara agar dapat berkembang dan dapat membangun secara ideal, harus memiliki wirausahawan sebesar 2\% dari jumlah penduduk (PBB). Wirausahawan yang dimaksud adalah yang sesuai dengan kriteria memiliki keahlian profesional, memiliki karakter entrepreneur yang kuat, memiliki motivasi berprestasi tinggi (McClelland) dan kemampuan berinovasi (Drucker) serta kemampuan dalam berafiliasi atau membangun aliansi. Berikut adalah grafik jumlah wirausaha di Indonesia dibanding Negara Lain:

\section{Grafik 1. Jumlah Entreprenuer di Indonesia dibanding Negara Lain}

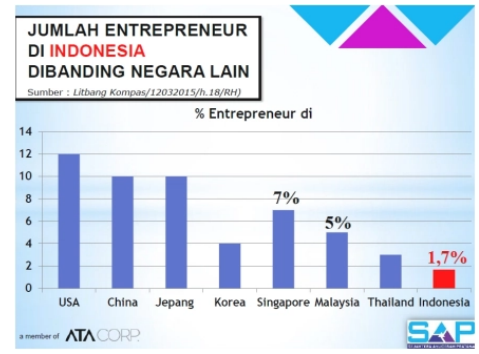

Sumber: Yoannasiagian.files.wordpress.com (2017)

Menteri Koperasi dan Usaha Kecil dan Menengah (UKM) Anak Agung Gede Ngurah Puspayoga menyebutkan, jumlah wirausaha Indonesia baru mencapai 3,1 persen dari jumlah penduduk. Rasio ini masih lebih rendah dibandingkan dengan negara lain seperti Malaysia 5 persen, China 10 persen, Singapura 7 persen, Jepang 11 persen maupun AS yang 12 persen. Berdasarkan data Badan Pusat Statistik (BPS) 2016 dengan jumlah penduduk 252 juta, jumlah wirausaha non pertanian yang menetap mencapai 7,8 juta orang atau 3,1 persen. Dengan demikian tingkat kewirausahaan Indonesia telah melampaui 2 persen dari populasi penduduk, sebagai syarat minimal suatu masyarakat akan sejahtera (kumparan.com). Bertumbuhnya wirausaha tak lepas dari peranan masyarakat bersama pemerintah yang terus mendorong, juga swasta dan kalangan mahasiswa atau kampus.

Pengetahuan kewirausahaan mendukung nilai-nilai wirausaha terutama bagi mahasiswa, sehingga diharapkan menumbuhkan jiwa usaha untuk berwirausaha. Sikap, dan motivasi terhadap minat mahasiswa sangat dibutuhkan bagi mahasiswa yang berwirausaha agar mampu mengidentifikasi peluang usaha, kemudian mendayagunakan peluang usaha untuk menciptakan peluang kerja baru. Minat mahasiswa dan pengetahuan mereka tentang kewirausahaan diharapkan akan membentuk kecenderungan mereka untuk membuka usaha baru di masa mendatang (Rifkhan, 2017: 2).

Populasi wirausaha penting, karena merekalah yang mampu melihat peluang, mengembangkan, dan menciptakan bisnis baru, sehingga tercipta lapangan kerja dan tumbuhnya perekonomian negara. Terlebih di zaman digital, nyaris tak ada kendala untuk memulai bisnis sehingga mendorong pesatnya pertumbuhan wirausaha.

Media publik saat ini jika dicermati sebenarnya tidak hanya bersumber dari media televisi tetapi juga banyak bersumber dari berbagai penggunaan media online yang berbasis internet.

Pengguna internet yang besar di Indonesia menjadi sebuah fenomena menarik. Pertumbuhan pengguna internet di indonesia yang sangat pesat akan berdampak ke berbagai sektor kehidupan sebut saja teknologi ponsel yang makin berubah berpengaruh terhadap cara belanja orang Indonesia yang mulai merambah ke belanja online di era digital. Dimana 100 juta pengguna internet merupakan potensi pasar yang besar serta akan mempengaruhi munculnya berbagai peluang bisnis baru (marketplus.co.id).

Pengguna internet di indonesia dari hari kehari semakin meningkat, hal itu pula membuat Indonesia menjadi salah satu negara pengguna internet terbesar di dunia. Perhitungan yang dilakukan pada akhir tahun 2012 ini menunjukan bahwa indonesia merupakan salah negara berkembang yang memiliki penduduk pemakai internet terbanyak melebihi negara maju seperti inggris dan prancis yang berada di urutan 8 dan 10. Analisa ini diambil dari beberapa sumber diantaranya adalah dilakukan oleh International Telecommunications Union (ITU) dan Nielsen Online, sehingga data yang diperoleh dapat dikatakan mendekati valid. Jika berdasarkan hasil catatan yang dirilis kepala riset Teknologi Global Mary Meeker, Indonesia menempati urutan ketiga pengguna internet tertingga dengan catatan pengguna mencapai 55 juta dari jumlah populasi yang ada di Indonesia Sedangkan data yang dirilis oleh Internet World Stats Indonesia menempati urutan 8 dari 10 negara terbesar pengguna internet diseluruh dunia dan mengalahkan inggris dan prancis yang hanya menempati urutan sembilan dan sepuluh. Sedangkan urutan pertama masih ditempati china. Dari data tersebut Indonesia menjadi 
negara yang memiliki potensi besar dalam percaturan bisnis global khususnya yang berabasis internet dalam bertransaksi maupun promosi (eraberita.com).

Adapun minat berwirausaha online dapat dipengaruhi faktor lainnya yaitu motivasi. Menurut Sukmadinata, motivasi merupakan kekuatan yang mampu mendorong atau menggerakkan seseorang individu untuk melakukan kegiatan dalam upaya mencapai suatu tujuan (2007: 60-61). Motivasi sebagai suatu kekuatan yang dapat mendorong seseorang untuk dapat melakukan suatu perbuatan atau kegiatan, termasuk kegiatan berwirausaha. Seseorang yang mempunyai motivasi tinggi terhadap keinginan untuk memulai usaha, maka akan mempunyai minat yang tinggi pula terhadap kegiatan untuk berwirausaha. Motivasi dapat dibedakan menjadi motivasi intrinsik maupun ektrinsik.

\section{A.Tinjauan Pustaka}

1) Landasan Teori

a. Penggunaan Media Berbasis Internet

Kata "Media" berasal dari bahasa latin dan merupakan bentuk jamak dari kata "medium" yang secara harfiah berarti "perantara" yaitu perantara sumber pesan dengan penerima pesan (2008: 6).

International Network (Internet) adalah sebuah jaringan komputer yang sangat besar terdiri dari jaringan-jaringan kecil yang saling terhubung yang menjangkau seluruh dunia (2007: 52). Menurut Yuhelizar (2008: 1), internet merupakan singkatan dari interconnected network karena fungsinya yang menghubungkan jaringan dari jaringan-jaringan computer yang ada di dunia. Dari satu fungsi itu, internet semakin berkembang dan memiliki banyak manfaat bagi perkembangan dunia.

Dunia internet kini sangat pesat, tanpa mengenal usia, tanpa mengenal jabatan, tanpa mengenal waktu, tanpa mengenal golongan, seakan dunia maya tanpa batas. Dunia internet adalah dunia dimana kita dapat mempermudah akses semua kegiatan rutin yang ada dengan memanfaatkan konsep teknologi.

Menurut Muhammad Adri, (2008) terdapat setidaknya empat kegiatan yang dilakukan dengan menggunakan internet yaitu browsing, resourcing, searching, consulting and communicating.

Internet juga menjadi sosial media yang memberikan terobosan untuk merubah pola pikir pada perkembangan saat ini untuk berwirausaha online, bisa memperkecil resiko untuk gagal dan mempermudah untuk memasarkan produk lebih luas tanpa biaya yang sangat tinggi. Untuk menjadi wirausaha yang sukses mahasiswa harus bisa memperluas jaringan yang luas untuk lebih berkomunikasi dengan yang lain (Herwaman Kartajaya, 2008) dengan cara menggunakan internet. Dikarenakan peran sosial media semakin diakui dalam mendongkrak kinerja dalam dunia bisnis.

Hal ini bisa dijadikan sebagai peluang yang bagus bagi wirausaha kedepanya guna menggali potensi berwirausaha melalui media sosial. Apalagi sekarang sudah ada sosial media yang menfasilitasi setiap orang untuk terhubung satu sama lain.

Berbagai uraian di atas maka dapat disimpulkan bahwa pemanfaatan atau penggunaan media berbasis internet adalah mempergunakan internet sebagai alat bantu dalam meningkatkan dan memperluas serta mengembangkan kemampuan dalam berbagai aspek salah satunya berwirausaha online, yang ditinjau dapat dari (1) frekuensi penggunaan internet, (2) lama penggunaan internet, (3) jenis penggunaan internet dan (4) manfaat dalam penggunaan internet.

\section{b. Motivasi Intrinsik}

Menurut Sardiman (2006) motivasi intrinsik adalah motif-motif yang menjadi aktif dan berfungsi tidak perlu dirangsang dari luar karena dalam diri setiap individu sudah ada dorongan untuk melakukan sesuatu. Dengan kata lain individu terdorong untuk bertingkah laku kearah tujuan tertentu tanpa adanya faktor pendorong dari luar. Seseorang cenderung akan bersemangat untuk menyelesaikan suatu kegiatan karena ada motivasi yang kuat dalam dirinya. Motivasi sebagai suatu pendorong yang mengubah energi dalam diri seseorang kedalam bentuk suatu kegiatan nyata untuk mencapai tujuan tertentu.

Menurut Syaiful (2008: 149-151), motivasi intrinsik atau motivasi yang berasal dari dalam pribadi diri seseorang. Motivasi intrinsik timbul dari dalam diri individu sendiri tanpa ada paksaan atau dorongan dari orang lain. Sedangkan menurut Singgih D. Gunarsa, (2008: 50), motivasi intrinsik merupakan dorongan atau kehendak yang kuat yang berasal dari dalam diri seseorang. Semakin kuat motivasi intrinsik yang dimiliki oleh seseorang, semakin besar kemungkinan ia memperlihatkan tingkah laku yang kuat untuk mencapai tujuan.

Motivasi intrinsik adalah motivasi yang berasal dari dalam individu, yang berarti seseorang melakukan suatu tindakan tidak berdasarkan dari dorongandorongan atau faktor-faktor lain yang berasal dari luar diri, contohnya self actualization need (keinginan untuk mengaktualisasikan diri). Terbentuknya motivasi intrinsik terjadi karena adanya keinginan yang timbul secara alamiah dari dalam yang membangkitkan semangat atau menggerakkan seseorang untuk melakukan sesuatu untuk mencapai kepuasan atau tujuan, karena manusia selalu mempunyai naluri untuk mencapai sesuatu maka melalui motivasi intrinsik inilah dapat mendorong seseorang untuk terlibat dalam sebuah aktivitas. Motivasi instrinsik timbul sebagai akibat dari dalam diri individu sendiri tanpa ada paksaan dorongan dari orang lain tetapi atas kemauan sendiri.

Bila seseorang telah memiliki motivasi intrinsik dalam dirinya, maka ia secara sadar akan melakukan suatu kegiatan yang tidak memelukan motivasi dari luar dirinya. Dalam aktivitas untuk memulai wirausaha motivasi intrinsik sangat diperlukan, terutama berwirausaha online. Seseorang yang tidak memiliki motivasi intrinsik sulit sekali melakukan aktivitas berwirausaha secara terus menerus. 
Motivasi intrinsik ini penting karena setiap individu mempunyai individual differences yang membedakan dengan orang lain. Individual differences ini meliputi kesenangan, tingkat kepuasan, kemampuan penyesuaian diri, tingkat emosi dan kerentanan. Salah satu pandangan tentang motivasi intrinsik menekankan pada determinasi diri, dimana dalam pandangan ini mereka percaya bahwa mereka melakukan sesuatu karena kemauan diri mereka sendiri bukan karena kesuksesan, pamor atau imbalan eksternal lainnya.

\section{c. Motivasi Ekstrinsik}

Motivasi ekstrinsik merupakan motivasi yang berasal dari luar diri seseorang atau dari luar suatu lingkungan pekerjaan, karena adanya pengaruh faktorfaktor lain dari luar itulah yang menyebabkan rangsangan dari luar menjadi motivasi ekstrinsik bagi individu. Dengan kata lain motivasi ekstrinsik membuat seseorang melakukan sesuatu untuk mendapatkan sesuatu yang lain yang menguntungkannya.

Menurut Singgih D. Gunarsa (2008: 51), yang dimaksud dengan motivasi ekstrinsik adalah segala sesuatu yang diperoleh melalui pengamatan sendiri, ataupun melalui saran, anjuran atau dorongan dari orang lain.

Motivasi ekstrinsik berbeda dari motivasi instrinsik karena dalam motivasi ini keinginan mahasiswa untuk berwirausaha online sangat dipengaruhi oleh adanya dorongan atau rangsangan dari luar. Menurut Sardiman (2006), motivasi ekstrinsik adalah motif-motif yang aktif dan berfungsinya karena adanya rangsangan atau dorongan dari luar. Motivasi ekstrinsik dapat membangkitkan motivasi intrinsik, sehingga motivasi ekstrinsik sangat diperlukan dalam memperkuat pencapaian tujuan yang telah ditetapkan.

Menurut Suhardi (2013), motivasi ekstrinsik adalah motivasi yang muncul karena adanya pengaruh dari luar diri seorang tersebut. Motivasi ini memiliki pemicu untuk membuat seseorang termotivasi. Pemicu ini dapat berupa uang, bonus, insentif, promosi jabatan, penghargaan, pujian dan sebagainya. Motivasi ekstrinsik memiliki kekuatan untuk mengubah kemauan seseorang dari tidak mau hingga mau melakukan sesuatu hal.

\section{d. Minat Berwirausaha Online}

Menurut Santoso dalam Wulandari (2013), mendefinisikan minat wirausaha adalah gejala psikis untuk memusatkan perhatian dan berbuat sesuatu terhadap wirausaha itu dengan perasaan senang karena membawa manfaat bagi dirinya.

Minat berwirausaha merupakan pemusatan perhatian pada wirausaha karena adanya rasa suka dan disertai keinginan mempelajari, mengetahui dan membuktikan lebih lanjut terhadap wirausaha. Minat berwirausaha muncul karena adanya pengetahuan dan informasi mengenai kewirausahaan yang kemudian dilanjutkan untuk berpartisipasi secara langsung dalam rangka mencari pengalaman dan akhirnya timbul keinginan untuk memperhatikan pengalaman yang telah didapatkan tersebut. Serta mempunyai perasaan senang dan mempunyai keinginan untuk terlibat dalam kegiatan pengambilan resiko, untuk menjalankan bisnis atau usaha sendiri dengan memanfaatkan peluang peluang bisnis yang ada, dan menciptakan bisnis baru dengan pendekatan inovatif. Minat berwirausaha tidak dimiliki dengan begitu saja, melainkan dapat dipupuk dan dikembangkan.

Menurut Zimmerer, Scarborough dan Wilson dalam Wedayanti dan Giantari (2016) menjadi wirausaha akan memiliki kebebasan dalam menentukan nasibnya sendiri dan berpeluang untuk berperan dalam masyarakat. Dengan memiliki usaha sendiri, seseorang dapat menentukan nasibnya sendiri dan tidak bergantung pada orang lain. Berwirausaha dapat mengembangkan diri sesuai dengan minat dan kemampuannya, sehingga membuat dirinya berarti bagi masyarakat. Menjadi wirausaha juga dapat berperan dalam masyarakat, karena dengan berwirausaha dapat menyediakan lapangan pekerjaan dan meningkatkan taraf hidup masyarakat sekitar. Berdasarkan uraian tersebut, dapat disimpulkan bahwa minat berwirausaha tidak selalu dibawa sejak lahir, melainkan dapat ditumbuhkan dengan pendidikan dan pelatihan.

Minat berwirausaha adalah rasa ketertarikan terhadap kegiatan berwirausaha yang menciptakan suatu usaha yang bermanfaat bagi diri sendiri dan lingkungan sekitar. Minat berwirausaha dipengaruhi oleh adanya soft skills yang tinggi karena menjadi seorang wirausaha dibutuhkan berbagai keterampilan dan karakter pribadi yang kuat. Berwirausaha akan membuat seseorang tidak ketergantungan pada orang lain karena menjadi wirausaha memiliki kebebasan untuk mencapai tujuan yang diimpikan. Kebebasan tersebut dapat berupa bebas menentukan bisnis yang diingkinkan, bebas mengatur jadwal operasional, dan tentunya bebas menentukan besarnya laba yang diinginkan. Kebebasan tersebutlah yang akan membuat seseorang tertarik atau berminat menjadi wirausaha.

Selain itu, berwirausaha dapat membantu pemerintah dalam mengatasi pengangguran karena akan terciptanya lapangan pekerjaan baru yang dapat menampung calon tenaga kerja. Hal ini akan bermanfaat bagi masyarakat, terutama masyarakat tempat usaha didirikan. Faktor-faktor yang mempengaruhi minat berwirausaha yaitu harapan pendapatan yang tinggi, dukungan dari lingkungan keluarga dan pendidikan kewirausahaan yang diterima. Indikator yang digunakan meliputi tidak ketergantungan pada orang lain, membantu lingkungan sosial dan perasaan senang menjadi wirausaha.

Zimmerer, Scarborough dan Wilson dalam Wedayanti dan Giantari (2016), menyatakan bahwa salah satu faktor pendorong pertumbuhan kewirausahaan disuatu negara terletak pada peranan universitas melalui penyelenggaraan pendidikan kewirausahaan.

Adapun faktor timbulnya minat menurut Crow and Crow dalam Rahmanto (2011: 17), terdiri dari tiga faktor yaitu: 
1. Faktor dorongan dari dalam (The factor inner urge)

Yaitu rasa ingin tahu atau dorongan untuk menghasilkan seseuatu yang batin dan berbeda. Dorongan ini dapat membuat seseorang berminat untuk mempelajari ilmu mekanik, melakukan penelitian ilmiah, atau aktivitas lain yang menantang. Faktor dorongan dalam yaitu persepsi seseorang mengenai diri sendiri, harga diri, harapan pribadi, kebutuhan, keinginan, kepuasan dan prestasi yang diharapkan.

2. Faktor motif sosial (The factor of social motif)

Yaitu minat dalam upaya mengembangkan diri dari dalam dan dalam ilmu pengetahuan, yang mungkin diilhami oleh hasrat untuk mendapatkan kemampuan dalam bekerja, atau adanya hasrat untuk memperoleh penghargaan dari keluarga atau teman.

3. Faktor emosional (Emotional Factor)

Yaitu minat yang berkaitan dengan perasaan dan emosi. Misalnya, keberhasilan akan menimbulkan perasaan puas dan meningkatkan minat, sedangkan kegagalan dapat menghilangkan minat seseorang.

\section{2) Kerangka Pemikiran}

Menurut Sugiyono (2009: 88), kerangka berpikir merupakan model konseptual tentang bagaimana teori berhubungan dengan berbagai faktor yang telah diidentifikasi sebagai suatu masalah yang penting. Artinya, kerangka berpikir merupakan sintesa tentang hubungan antar variabel yang disusun oleh beberapa teori yang telah dideskripsikan. Sugiyono (2009: 63), juga menegaskan bahwa hubungan antar variabel yang akan diteliti dapat dijelaskan melalui suatu model yang disebut dengan model penelitian.

Hubungan antar variabel yang akan dikaji dalam penelitian ini dapat ditunjukkan dengan variabel yaitu penggunaan media berbasi internet, motivasi intrinsik dan motivasi ekstrinsik sebagai variabel bebas terhadap minat berwirausaha online sebagai variabel terikat.

\section{Gambar 2. Kerangka Pemikiran}

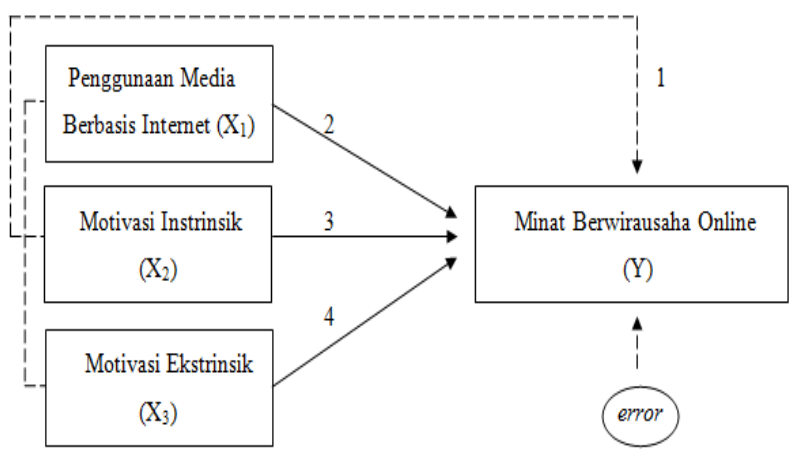

Sumber : Diolah Penulis (2019)

\section{3) Definisi Operasional Variabel}

Tabel 1. Definisi Operasional Variabel

\begin{tabular}{|c|c|c|c|c|}
\hline No & Variabel & $\begin{array}{c}\text { Definisi } \\
\text { Operasional }\end{array}$ & Indikator & Skala \\
\hline 1 & $\begin{array}{l}\text { Penggunaan Media } \\
\text { Berbasis Internet }\end{array}$ & $\begin{array}{l}\text { Alat bantu dalam } \\
\text { meningkatkan dan } \\
\text { memperluas serta } \\
\text { mengembangkan } \\
\text { kemampuan dalam } \\
\text { bidang berwirausaha } \\
\text { online }\end{array}$ & $\begin{array}{l}\text { - Frekuensi penggunaan } \\
\text { internet } \\
\text { - Lama penggunaan internet } \\
\text { - Jenis penggunaan akses } \\
\text { internet } \\
\text { - Manfaat dalam penggunaan } \\
\text { internet }\end{array}$ & Ordinal \\
\hline 2 & Motivasi Intrinsik & $\begin{array}{l}\text { Motivasi yang } \\
\text { timbul dari dalam } \\
\text { diri individu sendiri } \\
\text { tanpa ada paksaan } \\
\text { dorongan orang lain, } \\
\text { tetapi atas dasar } \\
\text { kemauan diri sendiri }\end{array}$ & $\begin{array}{l}\text { - Hasrat } \\
\text { - Dorongan } \\
\text { - Harapan } \\
\text { - Penghargaan }\end{array}$ & Ordinal \\
\hline 3 & Motivasi Ekstrimsik & $\begin{array}{lr}\text { Motivasi yang } \\
\text { timbul dan berfungsi } \\
\text { karena adanya } \\
\text { pengaruh dari luar } \\
\text { individu }\end{array}$ & $\begin{array}{l}\text { - Berwiraus aha sebagai } \\
\text { kegiatan menarik } \\
\text { - Lingkungan }\end{array}$ & Ordinal \\
\hline 4 & $\begin{array}{l}\text { Minat } \\
\text { Berwirausaha } \\
\text { Online }\end{array}$ & $\begin{array}{l}\text { Keinginan yang kuat } \\
\text { disertai dengan } \\
\text { usaha-usaha } \\
\text { seseorang individu } \\
\text { untuk berwirausaha } \\
\text { online }\end{array}$ & $\begin{array}{l}\text {-Faktor dorongan dari dalam } \\
\text { - Faktor motif sosial } \\
\text { - Faktor emosional }\end{array}$ & Ordinal \\
\hline
\end{tabular}

Sumber : Data Sekunder diolah (2019)

4) Hipotesis

Hipotesis dalam penelitian ini adalah :

1) Terdapat pengaruh positif penggunaan media berbasis internet, motivasi intrinsik dan motivasi ekstrisik terhadap minat berwirausaha online mahasiswa Universitas Tridinanti Palembang.

2) Terdapat pengaruh positif penggunaan media berbasis internet terhadap minat berwirausaha online mahasiswa Universitas Tridinanti Palembang.

3) Terdapat pengaruh positif motivasi intrinsik terhadap minat berwirausaha online mahasiswa Universitas Tridinanti Palembang.

4) Terdapat pengaruh motivasi ektrinsik terhadap minat berwirausaha online mahasiswa Universitas Tridinanti Palembang.

\section{B. Metodologi Penelitian}

1) Ruang Lingkup Penelitian

Ruang lingkup penelitian ini dibatasi untuk menganalisis pengaruh penggunaan media berbasis internet, motivasi intrinsik dan motivasi ekstrinsik terhadap minat berwirausaha online mahasiswa Universitas Tridinanti Palembang.

\section{2) Populasi dan Sampel}

Populasi dalam penelitian ini adalah seluruh mahasiswa Universitas Tridinanti Palembang tahun 2018/2019 yang berjumlah 5.718 mahasiswa (forlap.ristekdikti.go.id., 2019). Adapun pengambilan ukuran sampel dalam penelitian ini menggunakan rumus slovin:

$$
\mathrm{n}=\frac{\mathrm{N}}{1+\mathrm{N}(\mathrm{e})^{2}}
$$

dengan e sebesar 10\%, sehingga diperoleh 98,28 kemudian dibulatkan menjadi 100 responden.

Adapun teknik pengambilan sampel dengan menggunakan teknik proportionate stratified random 
sampling, teknik pengambilan sampel pada populasi yang heterogen dan berstrata dengan mengambil sampel dari tiap-tiap sub populasi yang jumlahnya disesuaikan dengan jumlah anggota dari masing-masing sub populasi secara acak. Teknik ini digunakan untuk tujuan memperoleh sampel yang representative dengan melihat populasi mahasiswa yang terdiri dari beberapa Fakultas untuk diambil wakilnya sebagai sampel.

\section{3) Metode Analisis Data}

\section{a. Statistik Deskriptif}

Statistik Deskriptif merupakan alat statistik yang berfungsi mendeskripsikan atau memberi gambaran terhadap objek yang diteliti melalui data sampel atau populasi sebagaimana adanya, tanpa melakukan analisis dan membuat kesimpulan yang berlaku umum dari data tersebut (Sugiyono, 2009). Pengujian dilakukan untuk mempermudah memahami variabel-variabel yang digunakan dalam penelitian

\section{b. Uji Validitas dan Realibilitas}

Menurut Sugiyono (2010: 267), uji validitas adalah derajat ketetapan antara data yang terjadi pada objek penelitian dengan daya yang dapat dilaporkan oleh penelitian. Dengan demikian data yang valid adalah data "yang tidak berbeda" antara data yang dilaporkan oleh peneliti dengan data yang sesungguhnya terjadi pada objek penelitian.

Sedangkan uji reliabilitas menurut Sugiyono (2010: 354) dilakukan untuk mengetahui seberapa jauh hasil pengukuran tetap konsisten apabila dilakukan pengukuran dua kali atau lebih terhadap gejala yang sama dengan menggunakan alat pengukur sama. Uji reliabilitas dilakukan untuk mengetahui apakah alat ukur yang dirancang dalam bentuk kuesioner dapat diandalkan, suatu alat ukur dapat diandalkan jika alat ukur tersebut digunakan berulangkali akan memberikan hasil yang relatif sama (tidak berbeda jauh).

\section{c. Analisis Regresi Linear Berganda}

Analisis regresi linier berganda digunakan untuk mengetahui ada tidaknya pengaruh penggunaan media berbasis internet, motivasi intrinsik dan motivasi ekstrinsik terhadap minat berwirausaha online mahasiswa Universitas Tridinanti Palembang baik secara parsial maupun simultan. Model hubungan nilai dengan variabel-variabel tersebut dapat disusun dalam fungsi atau persamaan sebagai berikut (Ghozali, 2005: 82) :

$$
\mathrm{Y}=\mathrm{a}+\mathrm{bx}_{1}+\mathrm{bx}_{2}+\mathrm{bx}_{3}+\mathrm{e}
$$

\section{Dimana :}

$$
\begin{aligned}
\mathrm{Y} & =\text { Minat Berwirausaha Online } \\
\mathrm{a} & =\text { Konstanta } \\
\mathrm{b} & =\text { Koefisien regresi variabel } \mathrm{X} \\
\mathrm{X}_{1} & =\text { Penggunaan Media Berbasis Internet } \\
\mathrm{X}_{2} & =\text { Motivasi Intrinsik } \\
\mathrm{X}_{3} & =\text { Motivasi Ekstrinsik } \\
\mathrm{e} & =\text { error }
\end{aligned}
$$

Dengan kriteria penerimaan sebagai berikut :

a. Jika Sig $\leq 0,05$ maka Ho diterima dan Ha ditolak yang artinya terdapat pengaruh yang signifikan antara pengaruh penggunaan media berbasis internet, motivasi intrinsik dan motivasi ekstrinsik terhadap minat berwirausaha online mahasiswa Universitas Tridinanti Palembang

b. Jika Sig $>0,05$ maka Ho ditolak dan Ha diterima yang artinya tidak terdapat pengaruh yang signifikan antara pengaruh penggunaan media berbasis internet, motivasi intrinsik dan motivasi ekstrinsik terhadap minat berwirausaha online mahasiswa Universitas Tridinanti Palembang

\section{d. Koefisien Determinasi $\left(R^{2}\right)$}

Menurut Ghozali (2013: 97), koefisien determinasi $\left(\mathrm{R}^{2}\right)$ pada intinya mengukur seberapa jauh kemampuan model dalam menerangkan variasi variabel dependen. Nilai koefisien determinasi adalah antara nol dan satu $\left(0<\mathrm{R}^{2}<1\right)$. Nilai $\mathrm{R}^{2}$ yang kecil berarti kemampuan variabel-variabel independen dalam menjelaskan variasi variabel dependen amat terbatas. Nilai yang mendekati satu variabel-variabel independen memberikan hampir semua informasi yang dibutuhkan untuk memprediksi variasi variabel dependen.

\section{e. Koefisien Korelasi}

Uji Korelasi digunakan untuk mengetahui seberapa besar hubungan antar variabel yang diujikan. Uji Korelasi dapat dilakukan dengan uji Pearson Test, Kendall Test, maupun Spearman Test. Jika Nilai Pearson Test, Kendall Test, maupun Spearman Test $=0$ maka tidak ada hubungan antara variabel $\mathrm{X}$ dan $\mathrm{Y}$. Namun apabila Nilai Pearson Test, Kendall Test, maupun Spearman Test $\neq 0$. Maka terdapat hubungan antara variabel $\mathrm{X}$ dan variabel $\mathrm{Y}$. Jika nilainya positif maka hubungannya positif dan jika nilainya negatif maka hubungannya pun negatif. Semakin mendekati 1, berarti hubungannya sangat erat dan semakin mendekati 0 , maka hubungannya sangat rendah.

\section{Pembahasan}

\section{A. Gambaran Umum Objek Penelitian}

Gambaran umum objek penelitian dilihat berdasarkan jenis kelamin dapat dilihat pada Tabel 2

Tabel 2. Jenis Kelamin Responden

\begin{tabular}{|l|l|l|}
\hline Jenis Kelamin & Frek. & Persen \\
\hline Laki-Laki & 39 & $39 \%$ \\
\hline Perempuan & 61 & $61 \%$ \\
\hline Total & 100 & $100 \%$ \\
\hline
\end{tabular}

Sumber : Data Primer diolah (2019)

Berdasarkan Tabel 2 dapat disimpulkan bahwa responden pada penelitian ini didominasi oleh responden berjenis kelamin perempuan sebesar $61 \%$, sisanya responden laki-laki 39\%. 


\section{B. Uji Validitas dan Realibilitas}

Uji validitas dan uji realibilitas data dilakukan untuk memastikan bahwa hasil kuesioner penelitian valid dan dapat dipercaya sebagai input penelitian serta memastikan data bersifat realibel atau memiliki kehandalan untuk dijadikan dasar penelitian. Hasil uji validitas data kuesioner dapat dilihat pada Tabel 3

Tabel 3. Uji Validitas

\begin{tabular}{|c|c|c|c|}
\hline Variabel & $\begin{array}{c}\text { No. } \\
\text { Pernyataan } \\
\end{array}$ & $\begin{array}{c}\text { Nilai Pearson } \\
\text { Correlation }\end{array}$ & Ket \\
\hline \multirow{4}{*}{$\begin{array}{c}\text { Penggunaan } \\
\text { Media } \\
\text { Berbasis } \\
\text { Internet }\left(\mathrm{X}_{1}\right)\end{array}$} & 1 & 0.794 & Valid \\
\hline & 2 & 0.757 & Valid \\
\hline & 3 & 0.818 & Valid \\
\hline & 4 & 0.752 & Valid \\
\hline \multirow{4}{*}{$\begin{array}{l}\text { Motivasi } \\
\text { Intrinsik } \\
\quad\left(\mathrm{X}_{2}\right)\end{array}$} & 1 & 0.675 & Valid \\
\hline & 2 & 0.835 & Valid \\
\hline & 3 & 0.733 & Valid \\
\hline & 4 & 0.663 & Valid \\
\hline \multirow{4}{*}{$\begin{array}{c}\text { Motivasi } \\
\text { Ekstrinsik } \\
\quad\left(\mathrm{X}_{3}\right)\end{array}$} & 1 & 0.846 & Valid \\
\hline & 2 & 0.703 & Valid \\
\hline & 3 & 0.647 & Valid \\
\hline & 4 & 0.819 & Valid \\
\hline \multirow{4}{*}{$\begin{array}{c}\text { Minat } \\
\text { Berwirausaha } \\
\text { Online (Y) }\end{array}$} & 1 & 0.751 & Valid \\
\hline & 2 & 0.864 & Valid \\
\hline & 3 & 0.786 & Valid \\
\hline & 4 & 0.644 & Valid \\
\hline
\end{tabular}

Sumber : Data Primer diolah (2019)

Berdasarkan Tabel 3 dapat dilihat bahwa semua butir pernyataan dari ketiga variabel yang digunakan semuanya valid karena nilai pearson colleration $>\mathrm{r}$ tabel $(0,195)$. Yang artinya semua butir pernyataan dari penelitian ini dapat dipercaya dan digunakan dalam penelitian.

Sedangkan hasil uji Realibilitas variabel penelitian dapat dilihat pada Tabel 4

Tabel 4. Uji Realibilitas

\begin{tabular}{|l|c|}
\hline \multicolumn{1}{|c|}{ Variabel } & $\begin{array}{c}\text { Nilai Cronbach } \\
\text { Alpha }\end{array}$ \\
\hline Penggunaan Media Berbasis Internet $\left(\mathrm{X}_{1}\right)$ & 0.785 \\
\hline Motivasi Intrinsik $\left(\mathrm{X}_{2}\right)$ & 0.700 \\
\hline Motivasi Ekstrinsik $\left(\mathrm{X}_{3}\right)$ & 0.753 \\
\hline
\end{tabular}

Sumber : Data Primer Diolah (2019)

Berdasarkan Tabel 4 dapat diketahui nilai alpha cronbach lebih besar dari 0,6, dimana nilai cronbach's alpha $>0,6$ berarti bahwa semua variabel realible atau dapat diandalkan untuk dilakukan penelitian.

\section{Analisis Regresi Linear Berganda}

Analisis regresi digunakan untuk mendapatkan pengaruh variabel-variabel bebas $\left(X_{1}, X_{2}\right.$, dan $\left.X_{3}\right)$ terhadap variabel terikat (Y). Pengolahan data dengan menggunakan analisis regresi linier berganda, dilakukan dengan beberapa tahapan untuk mencari hubungan antara variabel independen dan dependen. Hasil analisis regresi linear berganda dapat dilihat dari Tabel 5 berikut ini:
Tabel 5. Hasil Analisis Regresi Linear Berganda Coefficients $^{\text {a }}$

\begin{tabular}{|c|c|c|c|c|c|}
\hline \multirow[t]{2}{*}{ Model } & \multicolumn{2}{|c|}{$\begin{array}{c}\text { Unstandardized } \\
\text { Coefficients }\end{array}$} & $\begin{array}{l}\text { Standardized } \\
\text { Coeficients }\end{array}$ & $\mathrm{t}$ & Sig. \\
\hline & B & Std. Error & Beta & & \\
\hline 1 (Constant) & .872 & .764 & & 1.141 & .257 \\
\hline Penggunaan_Internet & .346 & .063 & .383 & 5.530 & .000 \\
\hline M_Intrinsik & .398 & .073 & .358 & 5.479 & .000 \\
\hline M_Ekstrinsik & .202 & .053 & .263 & 3.773 & .000 \\
\hline
\end{tabular}

a. Dependent Variable: Minat

Sumber : Data Primer diolah (2019)

Berdasarkan Tabel 5, maka didapat persamaan regresi sebagai berikut :

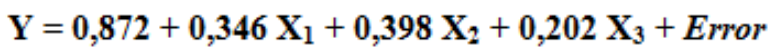

Persamaan regresi tersebut mempunyai arti bahwa :

a. Konstanta sebesar 0,872 dapat diartikan bahwa besarnya minat berwirausaha online sebesar 0,872 dengan asumsi variabel bebas lainnya tidak mengalami perubahan (konstan).

$b$. Penggunaan Media Berbasis Internet mempunyai koefisien regresi sebesar 0,346. Hal ini dapat diartikan bahwa apabila terjadi 1 peningkatan penggunaan media berbasis internet maka minat berwirausaha online akan mengalami peningkatan sebesar 0,346 dan ini signifikan.

c. Motivasi Intrinsik mempunyai koefisien regresi sebesar 0,398. Hal ini dapat diartikan bahwa apabila terjadi 1 pada variabel motivasi intrinsik maka nilai minat berwirausaha online akan mengalami peningkatan sebesar 0,398 dan ini signifikan.

d. Motivasi Ekstrinsik mempunyai koefisien regresi sebesar 0,202. Hal ini dapat diartikan bahwa apabila terjadi 1 pada variabel motivasi ekstrinsik maka nilai minat berwirausaha online akan mengalami peningkatan sebesar 0,202 dan ini signifikan.

\section{D. $U j i F$}

Uji F dilakukan untuk membuktikan ada atau tidaknya pengaruh variabel bebas terhadap variabel terikat secara bersama-sama atau yang sering disebut dengan uji regresi linear berganda. Hasil pengujian uji $F$ dapat dilihat pada Tabel 6 berikut ini :

Tabel 6. Hasil uji F (F test) ANOVA $^{\mathrm{b}}$

\begin{tabular}{|c|r|r|r|c|c|}
\hline Model & Sum of Squares & df & Mean Square & F & Sig. \\
\hline 1 Regression & 551.138 & 3 & 183.713 & 201.300 & $.000^{\mathrm{a}}$ \\
Residual & 87.612 & 96 & .913 & & \\
Total & 638.750 & 99 & & & \\
\hline
\end{tabular}

a. Predictors: (Constant), M Ekstrinsik, M Intrinsik, Penggunaan_Internet

b. Dependent Variable: Minat

Sumber : Data Primer Diolah (2019)

Berdasarkan Tabel 6 dapat dilihat bahwa Sig uji F sebesar 0,000 atau lebih kecil dari 0,05 yang berarti bahwa hipotesis awal diterima yang artinya terdapat 
pengaruh yang signifikan antara penggunaan media berbasis internet, motivasi intrinsik dan motivasi ekstrinsik terhadap minat berwirausaha online mahasiswa Universitas Tridinanti Palembang.

\section{E. Ujit}

Pengujian model regresi secara parsial digunakan untuk mengetahui apakah masing-masing variabel independen pembentuk model regresi secara individu memiliki pengaruh yang signifikan terhadap variabel dependen atau tidak. Untuk menguji hubungan tersebut, digunakan uji $t$, yakni dengan membandingkan nilai $t$ hitung dengan $\mathrm{t}$ tabel. Variabel independen pembentuk model regresi dikatakan berpengaruh signifikan jika $t$ hitung $>t$ tabel atau signifikan $<\alpha=0,05$. Hasil pengujian uji t dapat dilihat pada Tabel 7 berikut ini :

Tabel 7. Hasil uji t (t test)

\begin{tabular}{|l|l|r|r|}
\hline Variabel Independen & $\begin{array}{c}\text { Variabel } \\
\text { Dependen }\end{array}$ & $\mathbf{t}_{\text {hitung }}$ & \multicolumn{1}{l|}{ Sig. } \\
\hline Penggunaan Internet & Minat & 5.530 & .000 \\
\hline Motivasi Intrinsik & Berwirausaha & 5.479 & .000 \\
\cline { 3 - 4 } & Online & 3.773 & .000 \\
\hline
\end{tabular}

Sumber : Data Primer Diolah (2019)

Berdasarkan tabel 7 dapat diketahui bahwa hasil perhitungan diperoleh $\mathrm{t}$ hitung penggunaan media berbasis internet sebesar $5,530, \mathrm{t}$ hitung motivasi intrinsik sebesar 5,479 dan $\mathrm{t}$ hitung motivasi ekstrinsik sebesar 3,773 lebih besar daripada $\mathrm{t}$ tabel sebesar 1,9849 dengan signifikan sebesar $0,000<0,05$ maka dapat diartikan bahwa penggunaan media berbasis internet, motivasi intrinsik dan motivasi ekstrinsik berpengaruh signifikan terhadap minat berwirausaha online secara parsial.

\section{F. Koefisien Determinasi $\left(R^{2}\right)$}

Tabel 8. Hasil Koefisien Determinasi

\begin{tabular}{|l|r|r|r|r|}
\multicolumn{7}{|c|}{ Model Summary $^{\mathbf{b}}$} \\
\hline Model & $\mathrm{R}$ & R Square & $\begin{array}{c}\text { Adjusted R } \\
\text { Square }\end{array}$ & $\begin{array}{c}\text { Std. Error of the } \\
\text { Estimate }\end{array}$ \\
\hline 1 & $.929^{\mathrm{a}}$ & .863 & .859 & .955 \\
\hline
\end{tabular}

a. Predictors: (Constant), ), M_Ekstrinsik, M_Intrinsik, Penggunaan_Internet

b. Dependent Variable: Minat

Sumber : Data Primer Diolah (2019)

Berdasarkan tabel 8 diatas menunjukkan bahwa nilai R Square sebesar 0,863, hasil ini menunjukkan bahwa penggunaan media berbasis internet, motivasi intrinsik dan motivasi ekstrinsik mampu menjelaskan perubahan yang terjadi pada pengaruh minat berwirausaha online sebesar $86,3 \%$ dan sisanya $13,7 \%$ dipengaruhi oleh faktor-faktor lain yang tidak dijelaskan pada penelitian ini.

\section{G. Koefisien Korelasi}

Tabel 9. Hasil Koefisien Korelasi

\begin{tabular}{|ll|r|r|r|r|}
\hline & & $\begin{array}{c}\text { Penggunaan } \\
\text { Internet }\end{array}$ & $\begin{array}{c}\text { Motivasi } \\
\text { Intrinsik }\end{array}$ & $\begin{array}{c}\text { Motivasi } \\
\text { Ekstrinsik }\end{array}$ & \multicolumn{1}{c|}{ Minat } \\
\hline Penggunaa & Pearson Correlation & 1 & $.773^{* * *}$ & $.804^{* * *}$ & $.870^{* * *}$ \\
n_Internet & Sig. (2-tailed) & & .000 & .000 & .000 \\
& $\mathrm{~N}$ & 100 & 100 & 100 & 100 \\
\hline Motivasi & Pearson Correlation & $.773^{* * *}$ & 1 & $.776^{* * *}$ & $.858^{* * *}$ \\
Intrinsik & Sig. (2-tailed) & .000 & & .000 & .000 \\
& $\mathrm{~N}$ & 100 & 100 & 100 & 100 \\
\hline Motivasi & Pearson Correlation & $.804^{* * *}$ & $.776^{* *}$ & 1 & $.848^{* *}$ \\
Ekstrinsik & Sig. (2-tailed) & .000 & .000 & & .000 \\
& $\mathrm{~N}$ & 100 & 100 & 100 & 100 \\
\hline Minat & Pearson Correlation & $.870^{* * *}$ & $.858^{* * *}$ & $.848^{* * *}$ & 1 \\
& Sig. (2-tailed) & .000 & .000 & .000 & \\
& $\mathrm{~N}$ & 100 & 100 & 100 & 100 \\
\hline
\end{tabular}

Sumber : Data Primer Diolah (2019)

Berdasarkan tabel 9 menunjukkan bahwa nilai pearson correlations penggunaan media berbasis internet sebesar 0,870 , nilai pearson correlations motivasi intrinsik sebesar 0,858 dan nilai pearson correlations motivasi ekstrinsik terhadap kinerja karyawan sebesar 0,848 ini berarti penggunaan media berbasis internet, motivasi intrinsik dan motivasi ekstrinsik memiliki hubungan yang positif terhadap minat berwirausaha online.

\section{Kesimpulan}

Berdasarkan hasil penelitian didapatkan beberapa kesimpulan diantaranya: penggunaan media berbasis internet, motivasi intrinsik dan motivasi ekstrinsik berpengaruh signifikan terhadap minat berwirausaha online mahasiswa Universitas Tridinanti Palembang secara simultan dengan nilai Sig. 0,000. Penggunaan media berbasis internet, motivasi intrinsik dan motivasi ekstrinsik berpengaruh signifikan terhadap minat berwirausaha online secara parsial dengan sig masingmasing sebesar 0,000 atau sig $<\alpha=0,05$ dan $\mathrm{t}$ hitung $>\mathrm{t}$ tabel untuk penggunaan media berbasis internet sebesar 5,530, motivasi intrinsik sebesar 5,479 dan 3,773 untuk motivasi ekstrinsik. Penggunaan media berbasis internet menjadi variabel yang paling berpengaruh terhadap minat berwirausaha online mahasiswa Universitas Tridinanti Palembang.

\section{Daftar Pustaka}

Alwi Hasan. 2007. Kamus Besar Bahasa Indonesia. Jakarta: Balai Pustaka

Diarti Rosiatiningsih. 2014. Penggunan Internet di Indonesia Tembus $100 \quad$ Juta. http://marketplus.co.id/2014/02/penggunainternet-indonesia-tembus-100-jutal., diakses 22 Maret 2019

Djaali. 2008. Psikologi Pendidikan. Jakarta: Bumi Aksara

Hayat Masyur. 2019. 10 Negara Pengguna Internet di Dunia Termasuk Indonesia. https://www.era berita.com/10-negara-pengguna-internet- 
terbesar-di-dunia-termasuk-indonesial., diakses April 2019

https://forlap.ristekdikti.go.id., diakses pada 21 Maret 2019

Imam Ghozali. 2016. Aplikasi Analisis Multivariate dengan Program IBM SPSS 23 (Edisi 8), Cetakan ke VIII. Semarang: Badan Penerbit Universitas Diponegoro

Kumparan Bisnis. 2017. Jumlah Wirausaha Indonesia Masih 3.1 Persen dari Populasi. https://kumparan.com/@kumparanbisnis/jumlahwirausaha-indonesia-baru-31persen -daripopulasi., diakses 22 maret 2019

Muhammad Adri. 2008. Pemanfaatan Teknologi Informasi dalam Pengembangan Media pembelajaran. $\quad$ http:/ilmukomputer.org/wpcontent/uploads/2008/01/adri-multimediapengajaran.pdf, diakses 20 Maret 2019

Nana Syaodih Sukmawinata. 2007. Metode Penelitian Pendidikan. Bandung: PT Remaja Rosdakarya Offset

Rifkhan. 2016. Pengaruh Sikap, dan Motivasi Terhadap Minat Berwirausaha Mahasiswa Akuntasi Universitas Pamulang. Jurnal Ilmiah Akuntansi, Jilid 5 Terbitan 1. Universitas Pamulang

Sadirman. 2006. Interaksi dan Motivasi BelajarMengajar. Jakarta: PT Raja Grafindo Persada

Singgih D. Gunarsa. 2008. Psikologi Anak: Psikologi Perkembangan Anak dan Remaja. Jakarta: PT. BPK Gunung Mulia

Sugiyono. 2009. Metode Penelitian Bisnis. Bandung: Penerbit Alfabeta

Sugiono. 2010. Metode Penelitian Kuantitatif, Kualitatif. Bandung: Penerbit Alfabeta

Suhardi. 2013. The Science of Motivation (Kitab Motivasi). Jakarta: PT Gramedia

Wedayanti, N.P.A.A., \& Giantari, I.G.A.K. 2016. Peran Pendidikan Kewirausahaan dalam Memediasi Pengaruh Norma Subyektif Terhadap Niat Berwirausaha. E-Jurnal Manajemen, Vol. 05, No. 01. Bali: Universitas Udayana. Diunduh dari https://ojs.unud.ac.id/index.php/Manajemen/articl e/view/16295/11544, diakses 22 Maret 2019

Wulandari, S. (2013). Pengaruh Efikasi Diri Terhadap Minat Berwirausaha pada Siswa Kelas XII di SMK Negeri 1 Surabaya. Jurnal Pendidikan Tata Niaga (JPTN) Vol. 1 No. 1. Surabaya: Universitas Negeri Surabaya.

Yoannasiagian. 2017. Wirausaha (Entreprenuer). https://yoanasiagian.wordpress.com/., diakses 21 Maret 2019

Yuhelizar. 2008. 10 Jam Menguasai Internet Teknologi dan Aplikasinya. Jakarta: PT Elex Media Komputindo 